CRÓNICA

\title{
NICANOR PARRA, PROFESOR
}

\section{Leonardo Sanhueza}

Como es bien sabido, durante los años noventa, Nicanor Parra fue profesor en la Escuela de Ingeniería de la Universidad de Chile, donde enseñó literatura en un estilo muy particular. Esta crónica describe a ese profesor y da una idea de la influencia que desde allí generó.

It is well-known that in the decade of the 90s, Nicanor Parra was a professor at the School of Engineering of the University of Chile, where he taught literature with a very particular style. This article describes that professor and provides an idea of the influence he generated.

Los profesores nos volvieron locos

a preguntas que no venían al caso.

N. P.

ay muchas fotografías en que Nicanor Parra aparece como profesor, retratado en plena clase. En unas está de cara a sus alumnos, en otras escribe sobre el pizarrón o está atento a esa nada espesa y fan-

Leonardo Sanhueza (Temuco, 1974). Poeta chileno. Cronista. Entre otros libros, ha publicado Tres bóvedas (2003), Agua perra (2007), La ley de Schell (2010), Leseras (traducciones de Catulo, 2010), La edad del perro (2014) y El hijo del presidente (2014). También fue el compilador de Obra poética, de Rosamel del Valle (2000). Email: leosanhueza@yahoo.com 
tasmal que a veces sobrevuela con su silencio intermitente el espacio pedagógico.

Estuve revisándolas para hacer memoria, ya que entre ellas no son pocas las que registran un momento de mi propia experiencia, encuadrando un lapso importante de mi vida como estudiante en la Facultad de Ciencias Físicas y Matemáticas de la Universidad de Chile. No sólo son escenas que vi "con mis propios ojos", como se suele decir, a comienzos de los años noventa, sino que además pertenecen al campo de fuerzas que torció mi vida desde las ciencias hacia la literatura, pero que se han resuelto entre mis recuerdos de otro modo, con otro foco, con otro tiempo: son fotografías de lo que mi memoria no quiso o no pudo atrapar, abocada como estaba al instante previo o siguiente, a otro ángulo, a qué sé yo. Esa sensación se hace más patente en algunas imágenes que sólo muestran el pizarrón, entero rayado, ese mismo pizarrón que los alumnos mirábamos al final de la clase con cierta perplejidad, sin saber que veinte años más tarde su registro nos parecería ajeno aunque lo sabríamos propio, como un tiempo perdido que pretende recobrar su sitio en nuestro archivo mental. Son fotografías del descalce, como las del álbum familiar, que operan como pruebas del recuerdo, pero que nunca son el recuerdo en sí, sino sólo un atisbo, una guía para bucear en un agua más turbia y desdibujada.

Es una sensación extraña ésa, la de ver fotografías que muestran desde un punto de vista ajeno un recuerdo íntimo. Da cierto desasosiego enfrentarse a imágenes de las que uno presumiblemente fue testigo, pero que sólo a la fuerza logran encajar con la memoria y que producen así un efecto de irrealidad retrospectiva. Escribir sobre esos días es también penetrar en el misterioso nexo entre la memoria, la historia y la documentación, ya que a la larga los documentos se mimetizan entre los recuerdos auténticos.

Al ver esas fotos compruebo además que transmiten un mensaje equívoco. (A propósito de equívocos, debo hacer un paréntesis obligado, porque no terminaba de escribir las palabras "transmiten" y "mensaje" cuando recordé que justamente en una de esas clases salió al baile el modelo de Jakobson, que hasta entonces me parecía una verdad palmaria, tal como me lo enseñaron en el colegio, pero que a partir de ese día se me fue con su absoluta verdad a las arenas movedizas para siempre, como todo lo demás. Si el disco "Pare" transmite un mensaje, ¿quién 
es el emisor? ¿La Dirección de Tránsito? ¿La Ley? ¿Pepe Grillo? ¿Nadie? Pero donde Jakobson estalló en unos fuegos de artificio como de Looney Tunes fue en este artefacto parriano: "In case of fire / Do not use elevators / Use stairways / Unless otherwise instructed". ¿Quién es el emisor de esas "Instructions”? ¿El Tío Sam? ¿El Pato Donald? ¿Dios? ¿El pánico en persona? Y ese emisor X, cualquiera que sea, ¿es el mismo que, llegado el caso, dará "instrucciones en sentido contrario"? Cierre paréntesis). (Repito: cierre paréntesis). (¿Quién dijo eso?). (En fin, sigamos). El pizarrón de Parra, atiborrado de bote a bote con anotaciones de caligrafía característica y reconocible, habla ahora en esas fotos de una clase electrizada e hiperkinética, una pedagogía a todo vapor y sin tregua, un ritmo que no se condice, según recuerdo, con el silencio y la pausa que marcaban esa hora y media que, dos veces a la semana, a mediodía, aparecía como un intenso oasis de calma en el neurótico tráfago de la facultad. Es un malentendido, por supuesto, imaginar una clase vertiginosa a partir de un pizarrón caótico y saturado, pero no está de más considerarlo, porque en él hay algo sustancial sobre el profesor Parra.

Pero vamos por partes. En la mayoría de las fotos el pizarrón aparece lleno de textos, frases, palabras sueltas, poemas, artefactos, a veces dibujos; todas ellas fueron tomadas en la Escuela de Ingeniería, principalmente en el auditórium Humberto Fuenzalida del Departamento de Geología, pero también en otras dos salas de la facultad, desde fines de los años ochenta hasta mediados de los noventa, es decir, en las postrimerías de la dictadura y en la naciente democracia, cuando Parra se acercaba o ya pasaba las ocho décadas. Entiendo que la mayor parte de ese ciclo corresponde al seguimiento que hizo el entonces estudiante de ingeniería e incipiente fotógrafo y cineasta Marcelo Porta, que en diez sesiones acumuló unas doscientas fotos; el resto, actualmente desperdigado por aquí y por allá, fue obra de alumnos aficionados a la fotografía, como también de profesionales que a veces se dejaban caer en las clases, a ver qué había. Mezcladas en ese "corpus pedagógico", hay unas pocas fotos de Parra, creo que dos o tres, mucho más antiguas, que repiten el motivo, pero con el pizarrón poblado de signos matemáticos, ecuaciones, leyes de la física, el nombre de Galileo; evidentemente, son de su etapa como profesor de mecánica racional en el Instituto Pedagógico; es decir, son previas a 1968. Entre ambas situaciones, aunque 
las imágenes ahora pasan la llana (hasta hoy me encuentro con gente convencidísima, como la mistificación lo aguanta todo, de que Parra en la Escuela de Ingeniería hacía clases de física, como en el Pedagógico, e incluso de un raro embutido de física y literatura), hay un abismo, no sólo por los años transcurridos. Vale la pena aclarar ese entuerto. Para enseñar física hay que hablar, explicar, demostrar; hay que dictar cátedra literalmente. Los alumnos aprenden la ley de gravitación universal, el concepto de masa, el movimiento de un cuerpo en el plano inclinado, el torque, la fuerza centrípeta. Después aprenderán otras cosas, por ejemplo que todo eso está en crisis, que nada en el universo es tan así, que la luz no viaja en línea recta, que (quizás) existen los agujeros negros o que el tiempo no es, en absoluto, el metro de platino que nos enseñan los relojes. El profesor de física, tanto si enseña mecánica racional como si activa en los cerebros la dinamita fértil de la teoría cuántica, debe asumir su rol de maestro, de ministro del conocimiento. Pero cuando ese mismo profesor debe hablar de literatura, de poesía, de lenguaje, su cátedra se terremotea sobre sus bases, basculándose hacia el instinto, hacia las vísceras, y acaba volcándose hacia el silencio y el polvo levantado desde los adobes destrozados por ese sismo. Eso eran, al fin, las clases de Parra: un gran silencio, un silencio elocuente, como salido del terremoto de Chillán. Un silencio a punto de estallar y decir algo más acerca del futuro.

Efectivamente, Parra casi no hablaba en sus clases. Quiero decir: hablaba, pero lo hacía con gotario y, a pesar de su tono enfático, parecía hacerlo en clave, diciendo una cosa por otra o emitiendo juicios a veces sólo con una mirada, con un rictus socarrón, con una mano alzada en señal de rechazo o de sorpresa. Al pensar en esa mudez se me cruzan ahora por la cabeza tres impresiones: 1) Parra no hablaba porque ya era anciano, $y$, antes que el derroche de palabras, prefería soltar su discurso en pequeñas y medidísimas dosis letales como el cianuro; 2) Parra no hablaba porque esperaba, usando el silencio como carnada, que nosotros lo hiciéramos; y 3) simplemente estaba cansado y le daba una lata enorme "enseñar" cosas a estudiantes creídos de su inteligencia y a veces muy fanfarrones, como éramos nosotros; con su silencio parecía decirnos: "Considerad, muchachos, / Este gabán de fraile mendicante: / Soy profesor en un liceo obscuro, / He perdido la voz haciendo clases". Exagero, naturalmente, pero sólo para mostrar que el silencio de Parra 
no era en absoluto un producto de la timidez, como tampoco de la improvisación malograda, sino que era toda una construcción, una estrategia en cuyo revés podía leerse: "No contaban con mi astucia".

Recuerdo al respecto largos lapsos de tensión, en los que el profesor Parra, luego de escribir algo en el pizarrón, se rascaba la cabeza, se quedaba mirando la frase o se paseaba como un guardia del palacio de Buckingham frente a ella, de un lado al otro, con una mano en el mentón, sin abrir ni por un instante la boca (la frase podía ser, y en efecto alguna vez lo fue, uno de sus artefactos: "De boca cerrada no salen moscas").

Otro procedimiento habitual era el de la maleta. Parra solía llegar a clases premunido de una gran maleta o, en su defecto, de un gran bolso de cuero, en cuyo interior había decenas, cientos de libros, escogidos nunca supimos con qué criterio, supongo ahora que al tuntún. De la maleta podía salir Así habló Zaratustra de Nietzsche, el Curso de lingüistica general de Saussure o El fin de la historia de Fukuyama. Era como una tómbola en la que Parra metía la mano para sacar la bolita ganadora. Enseguida abría el libro en una página elegida al azar —o eso quería hacernos creer-y le pedía a un alumno que la leyera. Si el texto era provocador o sugerente, la máquina de llenar pizarrones se activaba y los estudiantes después continuaban el trabajo de batir la lengua. Ahora bien, si el texto era incomprensible, meramente retórico, aburridor, la máquina de llenar pizarrones se activaba justamente por ese lado, por el del pelambre crítico, y nos reíamos mucho descuerando la inoperancia del autor. Una variación muy desopilante de ese juego tenía lugar cuando en vez de un libro salía de la maleta el suplemento Artes y Letras, de El Mercurio, cuyos articulistas, ya fuera por la estupidez de su tema o por lo risible de su prosa, al cabo de un par de párrafos terminaban subidos al columpio iconoclasta, noqueados por el humor chillanejo.

Todo ese modus operandi, como se puede imaginar, desconcertaba a los estudiantes, porque a pesar de estar sólo en segundo año de Ingeniería ya se habían acostumbrado a otro tipo de profesores, que por originales y aun geniales que fueran eran hombres serios y formales, que necesitaban su tiempo para exponer una determinada cantidad de contenidos. De los profesores que conocí, el único que pudo tener algún punto de comparación con Parra fue el físico Igor Saavedra, cuyas clases de Introducción a la Física — curso que por lo demás podría haberse 
llamado sin más Introducción al Pensamiento Científico- incluían algunos paréntesis extracurriculares destinados simplemente a recordarnos que no estábamos muertos ni éramos vegetales, sino que éramos estudiantes universitarios y que por lo tanto nuestra única postura irrenunciable era tener los ojos muy abiertos a la realidad, porque la vida es demasiado corta - "Recuerde el alma dormida / avive el seso y despierte" - para andarla dilapidando o para cometer el pecado mortal de que nuestro encefalograma resultara plano mientras tomábamos apuntes como autómatas. Esos paréntesis, en el caso de Parra, eran el meollo del curso. Paréntesis tras paréntesis, al cabo de una hora y media de clase, cuando la sala comenzaba a vaciarse, aunque no habíamos aprendido nada específico, nuestro aprendizaje bailaba un nuevo estilo de baile: el pizarrón ya no daba abasto $\mathrm{y}$, a medida que iba quedándose solo con sus pedazos gastados de tiza, se reafirmaba como único y engañoso testimonio de aquel pausado caracoleo sin tema fijo - "cada loco con su tema", ésa era la premisa - que en cada vuelta había ido lanzando un aguijón tras otro en la cabeza de los estudiantes.

Egresar de ese curso era, pues, irse con la cabeza embanderillada como el lomo de un toro luego de la lid, con la ventaja sobre el bovino de que nunca llegaba el momento del sablazo de gracia. Al final del semestre de otoño de 1992, cuando estuve en ese curso como alumno, la deserción estudiantil fue catastrófica. Buena parte del curso abandonó, feliz, la Escuela de Ingeniería. Fue el empujón que necesitaban los desertores. Unos se fueron a escuelas de arte, otros se decantaron por las ciencias políticas, por la sociología, por el cine, por la danza contemporánea. Entre los que se quedaron, desde luego hubo quienes no acusaron recibo del chancacazo e, incólumes, siguieron su recto rumbo previsto hacia el éxito ingenieril, pero otros lo sintieron en el tuétano y sus vidas de ingenieros o científicos en ciernes ya no fueron las mismas que habrían sido con la intervención de cursos de "formación general", como se usa ahora en la falsa y patética moda de la "educación integral" (las humanidades como barniz cultural) que gobierna las universidades públicas y privadas. Ese curso de Parra del 92 fue una bomba de racimo. Supuestamente se centraba en El rey Lear, pero la bomba nos dejó pensando en Hamlet y en La tempestad. La Escuela de Ingeniería, tan pulcra y severa como era, había incubado con todo gusto a sus gremlins. Muy pronto, además, en la facultad comenzó una febril actividad 
de orden artístico, político y cultural. Las lecturas vespertinas de poesía eran cosa de todas las semanas, como también las actividades del Taller de Arte, la proliferación de "colectivos" de toda especie, los recitales de música alternativa o de punk o de lo que hubiera, las revistas no ingenieriles, las intervenciones poéticas espontáneas en el patio o los nutridos ciclos de cine alemán o francés organizados por estudiantes. En 1993, con sólo las patas y el buche, tres amigos organizamos un encuentro nacional de poesía llamado "La musiquilla de las pobres esferas", que duró cinco días y en el que participaron unos sesenta poetas, entre ellos Armando Uribe Arce, Tomás Harris, Carlos Cociña, David Turkeltaub, Clemente Riedemann y Jorge Teillier, que asistió ahí a su último homenaje en vida. La facultad en ocasiones no parecía un campus de ciencias exactas. La Escuela de Ingeniería se había vuelto un espacio de poesía en movimiento. Un espacio de inquietud, de curiosidad, de belleza.

Pero quizás estoy mintiendo demasiado. El infierno seguía siendo el infierno. Cómo esa facultad demente iba a convertirse en un espacio de ninguna cosa.

Mejor volvamos a las fotos. Imaginemos.

\section{2}

El registro documental de las clases de Nicanor Parra es una excepción interesante en el género de las "fotos de escritor", porque su tema es un aspecto biográfico específico y extraliterario, en este caso su vida académica: su vida laboral, su otra vida. Para ponderarlo, sólo se me ocurren los ejemplos exiguos de Felisberto Hernández y Boris Vian, fotografiados ambos en su faceta de músicos, que para los dos fue una base o un complemento de su literatura, tanto así que esas fotografías "musicales" - Felisberto sentado al piano o Vian soplando su trompinette - se han vuelto adecuadas ilustraciones de su quehacer literario, de sus ideas o de su carácter. Lo de Parra es distinto, ya que la pedagogía y el magisterio, a pesar de su extensa carrera docente de casi medio siglo ("Considerad, muchachos..."), e incluso si se tienen en cuenta sus pocos pero bien conocidos poemas sobre esos asuntos ("Los profesores nos volvieron locos..."), se relacionan sólo de una manera tangencial con la antipoesía y no son aspectos relevantes en la apreciación de su 
personalidad o su ideario. Y sin embargo ya es un hecho consumado: la imagen de Parra ha quedado en buena parte ligada a un pizarrón, con aun mayor intensidad que la de Gabriela Mistral, por ejemplo, lo que ya es mucho decir.

¿Por qué en sus fotos más famosas T. S. Eliot no aparece como burócrata o William Carlos Williams como médico? O mejor aun: ¿por qué no se identifica a Nabokov con fotos tomadas en sus célebres clases de literatura? Las fotos de escritores no suelen inmiscuirse en ese aspecto más bien prosaico - el trabajo, el dinero, la sobrevivencia, las labores extraliterarias-, sino que a menudo pretenden ser más evocadoras de una vida interior, un carácter, algunos ambientes íntimos, o bien se abocan a gestos, excentricidades, humores. Nabokov no hace clases, sino que caza mariposas. Kafka no timbra papeles, sino que sonríe en la playa. Y así. Hemingway patea una lata de cerveza, Huidobro empuña un revólver, Ginsberg se desnuda, De Rokha se enfrenta a un plato de comida o contempla unas gallinas deambulantes. La circunspección de Kavafis, la tristeza de Vallejo, los ojos de Onetti, la chasquilla de María Luisa Bombal, la camisa abierta de Pound, el estilo de Silvina Ocampo, la marinería de Neruda, la mueca displicente de Enrique Lihn. Y Borges, qué decir de Borges. Felisberto pianista o Boris Vian cantautor, ya lo dije, pero también René Char tocado con teatrales plumas de indio norteamericano junto a Picasso. O Tolstói de botas cosacas en charla con el joven Chéjov. O Robert Desnos completamente ido en alguna sesión de alucinógenos. Incluso puede meterse por ahí la dramática postrera imagen de Robert Walser, huellas sobre la nieve, o la última, penúltima, quién sabe, foto de Rimbaud. Los escritores y sus circunstancias se han vuelto, también, ellos mismos, gracias a la fotografía, una historia para contar, una ficción, un drama biográfico, un cuento chino, una fábula.

Las fotos de Parra frente a sus alumnos pertenecen a otra categoría, o bien están planteando la ficción desde un aspecto raro. No están enfocadas en un instante excepcional o irrepetible, como tampoco en una leyenda, sino en la cotidianidad rutinaria, aquella que año a año reiteraba el profesor, una y otra vez, frente a sus estudiantes incógnitos. Lo excepcional, irrepetible o legendario, el "mito" de las clases de Parra, se constituyó muy a posteriori, después de consagrado el malentendido de que esas clases además eran parte del sistema parriano, de la antipoesía 
misma, es decir, que ilustraban una poética, como los bares en las fotos de Jorge Teillier o el mar en las de Neruda. Es cierto que las clases mismas, con sus lancetas en medio del silencio, podían funcionar como una metáfora del quehacer parriano, porque eran una versión pública de sus cuadernos: cada clase podía, en efecto, ilustrar algunos procedimientos de la creación antipoética. Pero eso es invisible en las fotos y permanece en la memoria de quienes asistieron a esas demostraciones. Como decía, las fotos dejan una impresión equívoca, ya que muestran escenas totalmente alejadas de su ritmo original, que era mucho más cercano al del flujo del pensamiento y de la conversación chilena - la misma que Raúl Ruiz describió tan bien al encontrar su centro en el discurso errático o circunloquio flotante- que al de una cátedra de temas definidos. Es decir, aunque el profesor Parra estuviera hablando acerca de Heidegger o exponiendo sus ideas acerca del endecasílabo o la seguidilla como las métricas del castellano hablado en Chile, las fotos se arrancan con los tarros y hablan de la montaña rusa de la antipoesía. En ese sentido, no parecen fotos de una clase extravagante de literatura, sino de un taller literario "de autor". Es algo espurio, pero verosímil: Parra haciendo clases de Parra. Dicen las fotos, como si dijera Parra desde la cátedra a sus alumnos: "Suban, si les parece. / Claro que yo no respondo si bajan / Echando sangre por boca y narices".

La sala de clases de Parra, toda llena de ideas y provocaciones, vibra ahora en esas fotos como el lugar propio de la antipoesía, el Olimpo del cual ella baja sin bajar, quedándose para siempre ahí, en ese espacio ya mitologizado que parece haber olvidado que su única frágil memoria es esencialmente estudiantil, inmadura, primaveral, atenazada por esa difícil juventud que hacía del conocimiento, el aprendizaje y la especulación un ejercicio poético o un artefacto en ciernes. Fuera del mito, esas fotos son también la prueba de que esa otra cosa existió: esos jóvenes invisibles pero extraordinarios, las "mejores cabezas de mi generación", ahora todas detrás del lente, sus caras de asombro ante el futuro que, a veces imperceptiblemente, a veces mediante un martillazo, parecía bascularse en esas clases hacia un inesperado abismo de indeterminación vocacional. Era una crisis entre mil otras, desde luego, pero su poderío radicaba en que había nacido de algo que parecía del todo inofensivo para estudiantes de elite, cabros que ya se abanicaban con el cálculo diferencial o las abstracciones de la topología: boinas negras 
del conocimiento científico que de pronto se veían desestabilizados por algo que, a fin de cuentas, no era más que una mera clase de literatura, y ni eso.

A los dieciséis años, cuando salí del colegio, a fines de 1990, en Temuco, yo no disponía más que de una imagen muy difusa de Parra, que por lo demás no me venía del colegio. Es más, mis primeros vínculos escolares con la poesía en general, entendida en su exceso vitalista sobre los géneros literarios, no pertenecían al ámbito de la literatura, sino al de las matemáticas y las ciencias naturales. Estudiar me aburría mucho, pero yo era bueno para los números y los profesores del ramo siempre me tuvieron aguachado. En mis últimos dos años escolares, mis cursos de matemáticas eran una fiesta, casi clases particulares, y se remitían a resolver juegos de ingenio, leer cuentos árabes, calcular cuántas plumas tiene una gallina o buscar peculiaridades esotéricas en las series de los números primos o de los múltiplos de siete. Lo que más me gustaba eran los ejercicios aritméticos, siempre muy misteriosos, los cuadrados mágicos, las propiedades extrañas de los números. Me divertía hacer operaciones con números en sistemas no decimales, por ejemplo, cosa completamente inútil, pero que a los quince años me hizo entender los números como hoy entiendo las imágenes poéticas. Yo no quería estudiar, quería embarcarme. De hecho, antes de dar la Prueba de Aptitud Académica, una de mis alternativas a la Escuela de Ingeniería era la carrera de Construcción Naval en la Universidad Austral, en Valdivia. Ahora que lo digo, entiendo la razón de ese disparate. Aún recuerdo la orgullosa alegría con que mi profesora Silvia Villagrán, autora de todas esas triquiñuelas educativas, me invitó a tomar once en una confitería de Temuco cuando supo que me había ido muy bien en la Prueba de Aptitud de Matemáticas y que había decidido irme a Santiago, a la Universidad de Chile. Antes de despedirnos para siempre, mientras llegaba el garzón con la cuenta, sacó de no sé dónde sus dos tomos de la biblia del estudiante de matemáticas, el Calculus de Tom Apostol, los mismos dos tomos con que ella había estudiado en la universidad, y sin decir agua va los puso en mis manos. Quizás te sirvan, me dijo. Me sirvieron, y mucho, incluso para darme cuenta de que el tiempo 
de los juegos matemáticos había terminado y que yo no sería jamás un árabe famoso por saber calcular cuántos pájaros había en una nebulosa y ondulante bandada de estorninos. Me da pena pensar que todas esas esperanzas cifradas por la profesora Villagrán en el que fue su mejor alumno en mucho tiempo se estrellaron al fin con el destino mío, que no era ser un gran constructor de viaductos o un iluminado astrofísico, sino sólo un escritor que día a día, como el más limitado de los cretinos, se debate entre las cosas más elementales: su lengua materna, la letra "o" de "ojo" y la "a" de "ala", y todas sus historias, sus recuerdos, sus imaginaciones.

El caso es que a los diecisiete años llegué a la Escuela de Ingeniería con mis dos tomos del Calculus de Apostol bajo el brazo. En cuanto a Nicanor Parra, lo había leído poco y mal, pero lo estimaba sin recaudos. Supongo que lo situaba en el espectro de la veda cultural de mi tiempo, es decir, la dictadura, a cuyos productos prohibidos o mal vistos yo había tenido acceso gracias a una tía que había pertenecido al MIR y que, en cada visita suya a la casa familiar sureña, me dejaba alguna pista de esa dimensión desconocida: algún casete de Alfredo Zitarrosa, alguna revista Apsi ya arrugada de tanto camuflarla. Fue ella quien me contó que, si me iba a estudiar a Beaucheff, tendría clases con Nicanor Parra. Naturalmente, no le di la menor importancia. Qué importancia iba a darle: tenía trece años, me faltaban tres, casi cuatro años para entrar a la universidad. A los trece, tres o cuatro años son una eternidad. Pero ya sabemos: aunque los días sean interminables, "las semanas son cortas / Los meses pasan a toda carrera / Ylosañosparecequevolaran". En efecto: a los diecisiete ya estaba entrando a Beaucheff y, a los dieciocho, ya estaba sentado en la sala del profesor Parra.

Gracias a la biblioteca del Departamento de Estudios Humanísticos (Ejército 333), yo ya me había hecho una idea de quién era Parra. No era nada más que eso, una imagen construida a partir de Poemas y antipoemas, Versos de salón, Canciones rusas, todo mezclado con Sermones y prédicas del Cristo de Elqui y, también, con mis mitos adolescentes acerca de la contracultura y el imaginario de izquierda, en el que Nicanor Parra, a su pesar quizás, figuraba en primera fila junto a su hermana Violeta o las funciones a tablero vuelto de La Negra Ester. Supongo que mis compañeros de curso, aunque tampoco supieran mucho de él, también tenían alguna imagen suya en la cabeza. Digo más: nadie lo elegía a ciegas. 
Entre los cursos del Departamento de Estudios Humanísticos, el de Parra era siempre el más solicitado. Tenía sólo sesenta vacantes, pero postulaban cientos (casi digo miles), ya fuera porque lo consideraban un rito de paso o un privilegio universitario que muy pocos estudiantes chilenos podían tener, o porque era un curso fácil de aprobar y tenía los mejores horarios. En cualquier caso, las vacantes, como en todos los cursos de la facultad, se llenaban con los estudiantes que tuvieran mejor "prioridad académica", o sea mejor posición en un ranking que variaba cada semestre según no sé qué polinomio que relacionaba factores como las notas, la cantidad de cursos aprobados o la fecha de ingreso a la facultad. Naturalmente, esa medida de calidad académica no era garantía de nada en un curso de literatura, donde hasta los más duros estudiantes de ciencias podían verse transfigurados en perfectos tarados y arruinarlo todo. El curso de Parra en particular dependía mucho de sus alumnos, de su entusiasmo, su curiosidad, su apertura de mollera. Afortunadamente, la mayor parte de mis compañeros eran muy buenos en ese sentido; estudiantes de ingeniería excéntricos, le sacaban trote a su inteligencia en todas las direcciones posibles; era gente que no iba a la universidad "a estudiar", como pedía Cecilia Bolocco, sino a vivir una vida universitaria. Era cierto que no faltaba el cabeza de cubo Rubik monocromático, pero más cierto era que todos los demás, la mayoría, habían llegado al profesor Parra por un genuino interés intelectual, una especie de alegría creativa de estar ante una oportunidad irrepetible.

Como para echarle más leña a la expectación, en aquella primera clase del semestre de otoño de 1992 Nicanor Parra no llegó. Tampoco lo hizo en la segunda, ni en la tercera, creo, ni en la cuarta. Hacía unos meses había ganado el Premio Juan Rulfo en Guadalajara y, por esos días, andaba en Valencia, España, donde estaba exponiendo sus trabajos prácticos y artefactos junto a la poesía visual de Joan Brossa. En reemplazo, esas primeras clases las hizo el profesor Felipe Alliende. El curso estaba anunciado como un monográfico sobre El rey Lear, lo que hacía suponer que el reemplazante iba a contarnos algo de Shakespeare, de la historia del teatro, de la diferencia entre poesía lírica y poesía dramática, cualquier cosa por el estilo, pero no hizo nada de eso, sino que se dedicó a hablarnos de Parra y de la antipoesía. Ese cursillo exprés estaba hecho de manera didáctica, con toda la sapiencia pedagógica de un experto en educación como es Alliende, pero además contenía 
elementos de un retrato personal, amistoso, incluso admirativo, trazado por alguien que lo conocía en muchas facetas. Alliende combinaba muy bien su vocación académica formal con un sentido del humor consciente del efecto que producía la mezcla de solemnidad y socarronería; uno o dos años después, cuando fue mi primer profesor de latín, me contó por qué cuando joven había cambiado la teología por humanidades más profanas: mientras estudiaba en Italia, un escote romano lo hizo entrar en vereda. Por lo demás, ese humor académico, de happening, tendiente siempre a tomarle el pelo o bien a bajarle derechamente el moño a la "alta cultura", era muy propio del Departamento de Estudios Humanísticos; recordemos que en ese lugar, yo diría que incluso con más amplitud de alcances que Parra, había dejado su huella indeleble Enrique Lihn. De modo que Alliende, al mismo tiempo que hablaba de los antipoemas con la amabilidad de un maestro normalista, también se permitía hacerlo con la risa de quien había participado en la juerga de Adiós a Tarzán o en el festivo cincuentenario de Lihn, donde encarnó el rol hilarante de un obispo que bendecía en correcto latín al autor de $L a$ pieza oscura en aquel "Año de la Mutualidad del Yo".

No tengo noticias de otro curso universitario que, como ése de Parra del 92, haya contado con un prólogo semejante acerca del profesor. Una rareza más. El invunche estaba casi completo. Sólo faltaba el maestro. Cuando por fin Parra hizo su entrada al auditórium Fuenzalida, el aire de impaciencia ya podía cortarse con tijera. Comenzaba, pues, nuestra pequeña gran ceremonia de hacernos un poco más libres, más conscientes de nuestras palabras.

La asistencia era libre. En realidad, ningún curso en la facultad tenía como requisito ir a clases, tanto así que un alumno muy competente o estudioso podía aprobar incluso con un siete cualquier curso sin siquiera haberle visto la cara al profesor. Había casos, por supuesto, en que asistir era obligatorio de manera tácita, como los laboratorios de química o de electricidad, que se basaban en realizar algún trabajo práctico; también los había en que la asistencia era tan conveniente que, en los hechos, se volvía obligatoria. En el curso de Parra, la libertad de asistencia era libre en términos absolutos. Para aprobarlo daba lo mis- 
mo haber ido o no a clases. El único requisito era presentar un trabajo final, para cuya confección no hacía falta haberse asomado en la sala ni una sola vez. Pero de todos modos las clases solían ser muy concurridas: los sesenta alumnos a veces se volvían cien o más. Los "oyentes" venían de todas partes, no sólo de la escuela. Recuerdo que solían ir escritores, profesores, artistas, libreros, periodistas, como también acomodadores de autos o jubilados ociosos. La clase de Parra, en un tiempo en que las actividades culturales aún estaban en un tímido despegue, era una conferencia estable de todo el otoño, abierta a quien quisiera ir.

Parra, además, solía llegar acompañado por su hijo Juan de Dios, apodado Barraco, que según recuerdo oficiaba de chofer de la combi, o parramóvil, y asistente para transportar la maleta de libros. Otras veces, no recuerdo si ese año o el siguiente, llegaba además con su polola de entonces, una veinteañera preciosa, cuyo vínculo inverosímil con el poeta octogenario tardamos varias semanas en descubrir, seducidos como estábamos, en esa sala mayoritariamente masculina y llena de hormonales menores de edad (aún no se bajaba por ley de veintiuno a dieciocho la edad adulta), por esa misteriosa Pincoya terrestre que de cuando en cuando se asomaba en nuestro espacio estudiantil.

Una vez apareció Mauricio Redolés en el salón Fuenzalida, después de un curioso incidente televisivo que ahora es recordado como un escándalo o hito freak de la transición: la primera vez que alguien dijo un garabato, el adjetivo "culiao", en televisión. Redolés había sido invitado al programa El desjueves, del canal La Red, donde lo habían requerido a propósito de eso, por haber integrado a su repertorio el poema "El poeta y la muerte" de Parra y por ser el autor de un poema que por ahí decía: "Hay viejos culiaos que no creen que en un poema se pueda decir: viejo culiao". Ahora parece una estupidez, pero en mayo de 1992 fue una bomba de varios megatones. A veces conviene recordar cómo era el país en esos años. Decir "huevón" en radio o televisión era un acto suicida ante los órganos contralores, aunque la vulgaridad dictatorial estaba ya consagrada y prometía durar muchos años. Era entendible que se trataba más bien de un acto de cortesía, ya que el escándalo había salpicado al poeta, pero la presencia de Redolés en la sala de Parra fue un acto de liberación. Qué se creen. Todo el mundo en Chile dice "viejo culiao" y sabe muy bien qué quiere decir eso, como también sabe (aunque a veces no mucho) qué es "pegarse una buena cacha". Sí, Parra era también una inyección contra el totalitarismo remanente en aquellos 
pusilánimes primeros años de los noventa. Eran días en que decir públicamente que el poeta "se lo enchufa" a la muerte era un acto de liberación. Trágica y dramática liberación.

El curso de Parra tenía un peculiar sistema de evaluación. Nadie reprobaba, salvo que uno se hiciera el sueco y no diera ni luces de existencia. No había pruebas parciales ni examen final. La evaluación tenía sólo dos partes: una exposición sobre lo que cada alumno estimara conveniente (cada loco con su tema) y la presentación de una carpeta que cada quien debía decidir, a lo largo del semestre, con qué diablos llenaba.

Las exposiciones eran de lo más variopintas. Unas pocas tenían relación con Shakespeare, tema del curso, pero la mayoría se iba en direcciones inesperadas. Alguien llevó su guitarra y cantó. Otro hizo un montaje de video y esculturas. Creo que uno habló sobre electricidad. O tal vez se explayó acerca de las fronteras de la astronomía. O sobre las leyendas del rock progresivo. $\mathrm{O}$ el existencialismo. Yo me dediqué a la toponimia mapuche. No faltó, por cierto, el que trató de imitar a Parra, con artefactos literarios u objetos inspirados en los trabajos prácticos. Un estudiante no dijo nada, sino que danzó. La exposición más original, sin embargo, creo que fue la de un computín — como llamábamos a los fanáticos de la informática - que nos dejó boquiabiertos con algo que ahora parece muy simple: tomó las obras completas de Shakespeare digitalizadas e hizo un programa para analizarlas estadísticamente, según la frecuencia con que aparecían determinadas letras en ellas, para ver si había algún tipo de correlación interna o comparada con otras obras de su tiempo. Parece un juego de niños, pero en 1992 estábamos aún en la edad de piedra de internet, sin Google ni nada semejante, y ni hablar de Excel o Windows siquiera, y el estudiante había logrado bajar de la Universidad de Oxford las obras completas de Shakespeare y machucárselas para hacer un programa computacional de análisis de vocales o consonantes y descubrir, a partir de eso, algunas ideas plausibles.

En cuanto a las carpetas, es bien poco lo que puedo decir. Como eran secretas, nunca pude saber bien qué acumularon en ellas mis compañeros. Aunque algunos me dieron pistas: unos escribieron un diario de las clases, otros hicieron un collage de recortes de prensa; hubo uno 
que grabó las clases en VHS y luego entregó un resumen audiovisual en un casete; otro puso dentro una partitura de una composición para banda de batería, bajo y guitarra. Yo hice un mix: mis apuntes de clases, unos collages intervenidos con dibujos a grafito, una entrevista a Claudia di Girolamo (que hacía el papel de Cordelia en la versión de El rey Lear traducida por Parra, que se montaba por entonces en el teatro de la Universidad Católica), un resumen de mi exposición sobre toponimia mapuche, y no recuerdo qué más. Para muchos era una pesadilla tener que llenar una carpeta sin saber a qué instrucciones atenerse, pero eso mismo hacía que cada quien descubriera que ese trabajo no era un esfuerzo académico, sino una indagación personal. Uno hacía el ridículo ante sí mismo, tratando de ser original, pero con eso se exponía ante sus propias fragilidades. Aunque casi no había reglas, las carpetas resultaron ser una bitácora de una transformación interior.

Entrado el invierno de 1992, un día, en el auditórium Fuenzalida no volaba una mosca. Última clase. Era casi la una y media de la tarde, quedaban sólo unos minutos para que finalizara el curso. Ya era hora de almorzar, hacía más frío adentro que afuera, el aire estaba húmedo, quizás afuera estaba lloviendo y la lluvia lavaba otra vez la estatua del siempre pensativo poeta Alonso de Ercilla y su fiel machi anónima que le agita sus ramas de canelo sobre la cabeza. Ningún alumno quería que la clase terminara. Todo lo que creíamos seguro se había movido y seguía moviéndose. Quién lo iba a decir: los mejores cerebros de su generación conmovidos por el final del curso de literatura. Nadie aprendió nada, todos aprendieron todo. Parado ante sus compañeros, el último estudiante disertaba acerca de cualquier cosa. Ése era el único requisito: decir o hacer lo que a uno le viniera en gana. Mientras el alumno hablaba, el anciano profesor, a sus espaldas, escribía unos mensajes de despedida ("Adiós, muchachos") haciendo rechinar la tiza sobre el gran pizarrón verde que se extendía como una pantalla de cinerama. Nos decía que había que proteger los últimos cisnes de cuello negro, pero también que nos cuidáramos del amor, de la pasión, de la pareja humana.

\section{6}

$\mathrm{Al}$ año siguiente, fui otra vez a las clases de Parra. No a todas, ya que para ir debía hacer la cimarra en otros cursos. A veces le ayudaba con la maleta, otras veces conversamos en el camino de la sala a la 
combi. Una vez, después de una clase en que se había hablado de Pablo de Rokha, le dije que me gustaba mucho Escritura de Raimundo Contreras. ¿Y qué otro poeta chileno te gusta?, me preguntó. Varios. Anguita, por ejemplo. Buen poeta, me dijo, pero lo dijo tan seriamente que no supe si me estaba tomando el pelo o si de verdad estaba confesando un reconocimiento a esa poesía que hacía años había llamado despectivamente "hermética". En otra ocasión, o en la misma, ya no lo sé, salió al trote el asunto de que yo también era sureño, como él, como todos los poetas chilenos, y entonces me preguntó por mis poemas. Yo no escribo poesía, le dije. Era mentira, por supuesto: en mi bolso llevaba un cuaderno lleno. Me aterraba la idea, por lo demás improbable, de que me pidiera que le mostrara mis versos. Fue algo muy estúpido de mi parte, quizás hubiera sido buena idea mostrárselos, ya que eran muy malos y el porrazo habría sido fructífero. La mentira, en todo caso, me hizo entender algo: que yo no iba ni remotamente por el camino de Parra. Y al entenderlo entendí que había empezado a ser escritor, que ésa era mi vida, que la Escuela de Ingeniería sólo era una difícil y rebuscada manera de entrar por la ventana o por la chimenea a lo que soy ahora. Resultado: me antiparrié. En los veinte años siguientes, nunca más cruzamos una sola palabra.

Pero Parra seguía ahí, presente. En abril de 1994, con mi entonces compañero de ruta Nicolás Martínez y nuestro cómplice el impresor de Geología, hicimos unos diez mil panfletos de colores, alusivos al quincuagésimo sexto aniversario de la muerte de César Vallejo. Los confeccionamos según la estética de las amenazas anónimas, con letras de diario recortadas y pegadas. Decían cosas como "César Vallejo, te odio con ternura", "56 años sin César", "César va lejos". Compramos papel por kilo en la calle Eyzaguirre y, con una botella de coñac Tres Palos, nuestro amigo impresor se puso manos a la obra. La mañana del 15 de abril, sin aguacero, llovieron los panfletos en la facultad. Nos asomábamos en las clases de cálculo, de estadística, de electromagnetismo, y después del cañonazo de papeles el desconcierto era total mientras huíamos despavoridos. El penúltimo lanzamiento fue en la sala de Parra. Ahí no huimos, sino que esperamos, agazapados, la reacción. Al principio hubo indignación, pero luego, al leerse los panfletos, Parra sonrió y torció la clase hacia Vallejo. "Fue domingo en las claras orejas de mi burro / de mi burro peruano en el Perú (Perdonen la tristeza)". 
Al poco tiempo, creo que el 96, se acabaron los cursos de Parra. Con el tino propio de los ingenieros, la facultad ordenó un nuevo sistema de evaluación académica. Parra se puso a sí mismo un cero, un enorme cero que llenaba la papeleta. Todo ha terminado entre nosotros.

Esta crónica ha llegado a su fin, ya que sin Parra en la facultad ya no hay mucho que contar, salvo una cosa, muy personal. Un par de años después, terminé mis cursos de geología y tuve que hacer mi tesis. Como me gustaba la petrología ígnea y metamórfica, me interesé por un tema de tesis que hacía tiempo había ofrecido un profesor de la especialidad. Eran las rocas manchadas de Las Cruces, entre la Playa Grande y la Punta El Lacho. Recién cuando fuimos con mi profesor a reconocer el terreno, me di cuenta de la broma del destino. Mi tesis se trataba de descifrar el misterio de las piedras sobre las que reposa la casa de Nicanor Parra.

Un día, con chaleco de geólogo, con lupa, con martillo, pasé de Las Salinas a la Playa Chica por la calle donde vive él. Por un momento pensé tocar la puerta, decir algo, contar lo que estaba haciendo. No me atreví, soy corto de genio para esas cosas. "Después traté de cambiarme a otra roca, / Allí también grabé figuras, / Grabé un río, búfalos, / Grabé una serpiente". Ríos, búfalos, serpientes. En la poesía, algún día, quizás, hablaremos más largo y tendido. EP 